\title{
The Study of Obsession in Patrick McGrath's Asylum: Sexual Obsession, Obsessional Jealousy, Obsession with power
}

\author{
Esma Biroğlu \\ Student Programme of PhD \\ English literature and Language \\ Istanbul/ Turkey
}

\begin{abstract}
The study sheds light on different types of obsession in Asylum and how each type of obsession affects the main characters in the novel. Sexual obsession is one of the types of obsession discussed in Asylumvia the female protagonist, Stella. Stella's sexual obsession with Edgar who is a patient in the mental hospital destroys her sanity and ruins her life as well as that of her son and husband. Her obsession is catastrophic. The narrator describes Stella's actions and gives the reasons for each activity. The reasons are based on psychiatric reasoning and they help the readers judge Stella's behavior.Obsessional Jealousy is the second type of obsession in Asylum which is exhibited by Edgarwho suffers from a paranoid psychosis. As a result of jealousy, he murders his wife brutally and also contemplates of harming Stella when he suspects that she is being unfaithful. The third type of obsession in the story is the obsession with power through the psychiatric, Peter. Peter is obsessed with power and is filled with the desire to control Stella and marry her. The issues discussed in this novel are relevant even in the contemporary world effectively. The study further explores the definition and history of obsession as well as the critical reception of the story.
\end{abstract}

Keywords: asylum,sexual obsession,power, obsessional jealousy,mental disorder

\section{Introduction}

Obsessions occur as a result of misinterpretation of thoughts that are significant in life but at the same time catastrophic. Such thoughts are unwanted as they lead to negative consequences. Most people experience such thoughts which are intrusive. When these thoughts are not interpreted effectively, people can suffer obsessions of different kinds. If one manages to reduce misinterpretation of such thoughts then he or she will succeed in lowering obsessions. Failure to understand the thoughts correctly increases the rate of obsession which affects the person obsessed as well as those around him/her (McKay et al. 240). When there is a conflict in thoughts, there arises a desire of either resolving the issues by adhering to the thoughts or coping with the thoughts.

Sociologists define obsessions as ideas, images or thoughts that do not go away. People affected by obsessivecompulsive disorder experience thoughts that cannot be dealt with through avoidance (De Silva 152).ObsessiveCompulsive Disorder is believed to contain an element of genetic as it sometimes runs in families. The disorder is however sometimes developed as a result of life situations and habits developed from childhood or over some time. An individual with OCD experiences a series of thoughts that he/she does not want as well as sexual thoughts that do not go away with time. One also may experience images of harming a loved one as well as getting hurt. People who are obsessed exhibit signs of depression, worrying too much (Menzies and De Silva 81) and feeling neglected. What is more, they fail to maintain relationships with friends and spouse. Their productivity in society also decrease and their quality of life deteriorate. As matter of fact, they sometimes recognize the magnitude of their behaviors but trying to stop the obsession causes stress and anxiety.

Obsession with power is a personality disorder whereby the individual exhibits power strivings of excessive power(Mills 5). The obsessed people tend to control and harm those around themIn fact, they lack empathy for others, that is, and they are indifferent to the suffering of the others. They always try to seize the opportunity to expand their power. They have the tendency to identify targeted individuals or group as worthless and victims. In fact, obsession with power poisons the personality, corrupts the mind and causes destructiveness.

Obsession exists in the postmodern era and is more diversified as people are obsessed with something like a smartphone (Veale and Alison 13). People obsessed with phones purchase the latest model of phones and are on their phone most of the time. The person becomes angry when there is a lack of network coverage or the phone shuts down(Van et al. 1). This obsession impacts their life as it is linked to obsessive-compulsive disorder. 
Sexual obsession is also common in the postmodern era as there are people who leave their families and flee with a person they are obsessed with. A sexually obsessed person is mostly not in a state of mind of making informed decisions and that is why he/she ignores the impact of the actions that he/she takes.

Throughout history, people have experienced different types of obsessions which have affected them as well as those around them. Obsession is not dangerous if it is moderate but when it becomes extreme it becomes fatal. Extreme obsession is treated medically as well as through therapies. The success of recovery however as depends on severity and support from family and friends as well as the psychiatrist's expertise.

\section{Asylum}

It is with no doubt that the novel presents a compelling story that revolves around the Stella's life and how her actions affect her life and her family. Stella goes to live with her husband who is a deputy superintendent in mental asylum. She is unhappy with her husband who works most of the time. She meets Edgar who is a patient in the asylum. He has killed and beheaded his wife. Edgar starts to work in the vegetable garden and he tells Stella that his wife cheated on him. Stella thinks that "hewas a guilty ofpassion: andpassion, in essence, was good" (McGrath15). With Edgar she starts to glimpse a new perspectiveother than from Max's point of view.

During their regular meeting, she develops a sexual obsession and what follows affects her as well as her husband and son (Treas Jonathan and Zoya 45). She helps Edgar to escape from the asylum, leaves her family and joins Edgar in London. Edgar starts to get jealous believing that Stella and his friend, Nick sleep together. He wants to kill Stella but he is not enough drunk to do so.Later, Edgar is caught and brought back to the asylum whereas Stella is brought to her house.

Psychiatric,Peteris obsessed with power and wants to control Stella. He takes advantage when Stella comes to the hospital to be treated after losing her son who drowns while she is watching and does nothing. Max wonders why she watched their son drown and could not even shout for help. She explains that as a wife she is expected to remain quiet, but the truth is that she was depressed for not being with Edger who she is sexually obsessed with (Reisman 158). Stella commits suicide when she attends the yearly party with the hope of seeing Edgar but fails to see him.

Asylum passes all tests of gothic literature as it contains elements such as romance, death, lust, wonder and mystery. One of the new gothic elementsin the novel is psychological horror that stems from the state of passivity of mother at that moment of son's death.

Asylum invites the readers to rethink about their moral judgments about paternalism, motherhood, mental disorder, criminal insanity, the institution of marriage and the mental hospital.Obsession is a theme that is evident in theAsylum. There are three types of obsession in the story namely sexual obsession, obsessional jealousy and obsession with power.

\section{Sexual Obsession}

Sexual obsession is an extreme urge for sex that makes one take unsound decisions when it comes to relationships and other aspects in life (Gordon 345). This type of obsession is evident through the principal protagonist Stella who is obsessed with Edgar:

She saw him as a charming rogue. She couldn't oppose him at all; it was not possible for she had started to surrender herself and no longer felt distinct and separate from him, and instead that she was incomplete without him. (McGrath 34)

Stella is the wife of Max Raphael and they have a son who is ten years old. Max works at a psychiatric hospital near London. He is the deputy superintendent who hopes to be promoted to superintendent but his dreams are shuttered by his wife (Reisman 171). Her obsession for Edger who is a patient in the hospital ruins her life as that of those around her.

According to the narrator, Max was not a man who seemed to satisfy a woman of Stella's caliber. Although he was a competent administrator, he was weak and was not imaginative. Edgar was the opposite of Max. He was handsome and a man of artistic sense. She states:

Hewas a big manwith broad shoulders and a heavy build, well-fleshed out on the chest and hips and belly, and a soft White skin. He had good hands, she noticed, large and slender, the fine, strong, sensitive hands of an artist. Therewas no hair on his body. (McGrath 12)

Stella admits in her inner world that she is attracted to him almost from the start. She tries to ignore her feelings toward Edgar since she is a married woman and a mother. But Edgar's presence near her house everyday makes it difficult for her to control her passion. She invents pretexts for seeing him and at the same time she wonders: 
It was absurd to think that talking to a patient in the vegetable garden could amount to anything. But if it was trivial, why did she have to conduct this argument with herself? Because of her growing sexual warmth for the man, which she foolishly indulged in this oblique manner, seeking his company, allowing him into her imagination.(McGrath13)

The sexual intercourse is inevitable. Stella considers their first sleeping as a moment of madness and this sexual intercourse will never be repeated and she will bury her guilty secret.But "the violence of feeling he had aroused in her would shatter the constraints of caution and common sense" (McGrath 22). She starts not to care about anything or anybody.

Her efforts to join several of the hospital committees and generally to pull her weight as senior staff wives are supposed to are meaningless and nonsense now. What only haunts her is the passion toward the man who has danced like a dream on the dance floor:

she functioned as normally as she could at home but she was never properly there. Her day became focused on that one point in time when she waited with rising excitement in the gloom of the cricket pavilion. She was ready for him, on the blankets, and sink down with her, and she lost herself completely, when she reached for him and felt his strong hands on her body. (McGrath 35)

The constant adulterous acts lead to a sexual obsession to the extent that she cannot do without Edger and is willing to do anything to be with him. She starts to expectfrom him so much that her husband cannot offer. Furthermore, being with Edger is the only way of escaping from her marriage. Stellais not contented with a husband, a child and a home:

Stella is in a normal marriage. A husband, a home, a child, reasonable contentment, but being a good wife and mother is not enough to make her happy. She finds her life stifling and unsatisfying, and she eventually becomes depressed and desperate. (McGrath 214)

Stella is exceptionally obsessed sexually to the extent that she brings Edgar to her marital bed. Bringing Edgar in her marital bed is contrary to social values which encourage moral values and respect of marriage institution as well as prohibit adultery (Oakley 34). Although at some point Stella confesses of her sexual relationship and vows to end the relationship, it does not happen. Their relationship becomes intense and after some times the location of where they have sex changes. The location of meeting shifts after Edgar escapes from the hospital with the help of Stella.

The escape of Edgar does not, however, mean that the obsession of Stella is over. She has to find a way of being with Edgar after he telephones her. She lies to her husband that she is going on shopping trips to London. They enjoy in London for a few weeks, and jealousy ofEdgar that leads himto murder his wife is evident towards Stella. He is jealous because he thinks Stella is now having sex with his friend Nick who takes Stella to a safe place. When she goes back to look for Edgar, she doesnot find him but instead she finds the police who bring her back home. Obviously, she does not return to her domestic role. Instead, she withdraws herself from her family.

Her sexual obsession makes her husband unable to secure promotion in the hospital as the escape of Edgar raises suspicion that it is her who has helped him to escape. It is almost sure that she has involved in the patient's disappearance and it is now clear that neither Stella nor Max will have the life they have had before this incidence (Reisman 160).

The extent of her sexual obsession also can be perceived via the death of her son as she watches him drowning instead of helping him. Stella loses her contact with the external world. She is distracted and distanced. She is careless about the safety of Charlie. She does not pursue Charlie's movement in the school picnic. She is supposed to check Charlie who gets close to the edge of the pond. At the moment of carelessness, Charlie drowns in the pond. Stella only watches Charlie "who was in deeper water now, trying to scramble upright and flailing around and shouting" (McGrath200). She does not try to save him because she is too numb to shout or to act.Instead, she sits "smoking her cigarette,turning her head away,then back, ten away again, as an indistinct figure struggled in the water. Her numbness toward her son's death is attributed to her despair about her life without Edgar. As a matter of fact, Stella suffers excessive depression which is an impact of extreme obsession.

The consequences of obsession make a person to be judged mercilessly by the society (Tseng and Jing 60). The hideous result of her obsession is becoming a morally culpable in the view of the society:

What horrified [people] was that she had made no noiseand hadn't moved. When they properly understood this it all changed, because the she was a mother who'd watched her child drown and done nothing to save him. It was unnatural, they said. It was evil. They couldn't understand it: she has no feelings, they said, she isn't human, she is a monster. Or perhaps she's mad. (McGrath 202)

Stella is admitted to asylum not as a wife of a psychiatric who was a deputy superintendent in that place but as a patient who suffers clinical depression. During her staying in the mental hospital, she pretends that she suffers because of the death of her son telling her psychiatric about her dreams of a screaming child. 
But " the truth was that her suffering was not remorse for the death of child, the truth was that she was still obsessed with Edgar Stark, to the virtual exclusion of everything else(McGrath 251). What is more, she pretends that she does not care about Edgar. She asks for a job in the laundry and sits alone on her bench. The reason behind her deeds is her hope to be allowed to attend the dance in order to see Edgar. Actually, her extreme obsession is manifested when she wears her white wedding gown and goes to see Edgar in the hospital, and when she fails to see him, she commits suicide.

The theme of sexual obsession is very evident in Asylum.Obsession makes a person unproductive in society as well as in the family. If one is married as in the case of Stella she loses the ability to maintain the relationship as a result of obsessive thoughts. Stella finds it difficult to relate well to her husband as well as her son Charlie.

Extreme obsession can be medically dealt with by use of drugs that are used to treat anxiety. However, it is advisable to use medication together with psychotherapy for treatment to be effective (Coles and Ariel 186).Stella is taken to the hospital where Peter who is the psychiatrist is expected to treat her although he fails to do as effectively as he is obsessed with her.

\section{Obsessional Jealousy}

Jealousy is a phenomenon that entails different components such as fear, sadness, and anger in extreme cases of hatred. Obsessional jealousy is a disorder that is in most of the times unrecognizable (Sheikhmoonesi 23). A person suffering from obsessional jealousy may harm himself or the person he suspects that is unfaithful (McKay et al. 241). Jealousy sometimes happens when someone feels the threat of losing a partner or admires someone else partner to the extent that he/she contemplates of what he/she can do to get the person. The concern of losing the person one loves is what leads one to be obsessed with thoughts that the partner is unfaithful and therefore requires to be monitored. The person, however, lacks evidence of unfaithfulness. The obsession in extreme cases leads to murder as in the case of Edgar in Asylum who due to obsessional jealousy kills his wife.

Edgar is obsessed with jealousy and brutally murders his wife and beheads her.He calls his wife a whore, despite the fact he has no evidence:

He claimed to have a wealth of evidenceof her infidelity, but when asked for it produced only trivial everyday occurrences into which he read bizarre, extravagant meanings. A flushing of toilet, a stain on the floor, the placement of a box of washing powder on a window still, these were the sorts of things that signified.(McGrath 8)

This obsession is also manifested when he are in London with Stella. Edgar bashes Stella, but she doesnot seem to recognize immediately that she is dealing with a dangerous man (Reisman 165). Edger is jealous, and when they are in London, he beats his friend Nick for suspecting that he is having sex with Stella. This jealousy is what makes him contemplate of killing her by use of a knife that Stella hears while he is sharpening. However, he uses it to cut an orange that he shares with Stella and Nick. He does not kill Stella because he is not drunk enough to do so or maybe he cannot justify his suspicions. When Stella sees that her life is in danger, she goes with Nick to sleep in another safe house, but Edger is not ready to leave Stella alone. He goes to the door of the house and bangs it loudly until the two are terrified.

Jealousy is reasonable if it is in moderation as it is an indicator that we care for another person. However, when it becomes extreme, it becomes a disorder which needs to be treated by a psychiatrist. People with morbid jealousy have obsessive thoughts about love as well as thoughts of unfaithfulness. Jealousy is activated by a love hormone referred to as oxytocin (Wells et al. 659). Obsessional jealousy makes a person find it difficult to put the thoughts of unfaithfulness out of his/her mind. In Asylum Edgar feels that his wife is unfaithful and hence, he kills her brutally. He also suspects that Stella is having an intimate relationship with his friend Nick although he has no evidence. In extreme cases, obsessional jealousy leads to murder and even suicide cases (Buss and Mike 170).People who are obsessed with jealousy also tend to be violent. Edgar engages Nick in a fight when they are in London (McGrath 176). This obsession can be treated medically or through psychotherapy as in the case of Edgar who is admitted in the mental hospital.

\section{Obsession with Power}

The obsessed person with power is defined as an individual who displays prolonged and acute manifestation of intense and extensive power strivings(Charny 3). The obsessed person has a great hunger for controlling the people around him/her and dominating everything all the time. Power obsession ruins one's personality. Peter, psychiatric, is obsessed with power in Asylum. When Stella is brought to the hospital, Peter's professional interest in Stella is suspiciously personal, and his choice to treat her is an illustration of his need for love or power in her. Peter's love for power becomes evident in his reaction to Stella's return to the hospital as a patient: 
Now that I had her here in the female wing I relished the prospect of stripping away her defenses and opening her up, seeing what that psyche of hers really looked like. I understood of course that she would resist me, but we had time. (McGrath 212)

This manifests his desire to control Stella. What is more, the desire for dominating Stella is the motivating drive in his personal and professional life. "Exercising control is also part of his sexual fantasies. He wants to subdue Stella, to mentally undress her, and so long as she eventually yields to his treatment" (Reisman 168). Peter wants her not only as a patient but as a wife. He admires her as she is a woman of taste and he believes that she fits his class. She thinks that she is the right person who should own her and not Edger (McGrath 125).

He is obsessed with possessing her as part of his furniture, art or books. He terms her one of his objects that he treasures. Peter also sees himself as better than Edgar and Max. Since he is the superintendent of the hospital, he feels that he is entitled to anything including marrying Stella. Peter is obsessed with controlling Stella to the extent that he talks to her husband about his intentions to marry her and asks Max to divorce her. He feels that he is in a position to treat Stella better than the way Max does (McGrath 30). His obsession blinds him to the extent that he does not respect moral boundaries His arrogance, unethical behavior concerning his profession and selfishness are visible in this incidence (Reisman 170).

Peter's obsession with power is also manifested as he is the one who makes sure that Stella comes to be treated in the hospital where her husband was a superintendent until he resigned after it was clear that she was in a sexual relationship with Edgar. Since he is in control of Stella, he is almost sure that she will not reject his proposal of marriage. He is the superintendent of the hospital, and he is the one who will determine whether Stella will be released from the hospital or not. "It is because he is a doctor that he is believed to possess these powers" (McGrath 275). This is because he is the one in charge of certifying that the patient has recovered and proceeding to apply for discharge through the Home Officer. When Peter knows that Stella has put an end to her life because she has been obsessed with Edgar, although he praises Stella before, he starts to play the role of a victim who is manipulated by her. "He does not question his actions nor does he take any responsibility. Instead, he hides behind his professional and social authority( Reisman 170).

His obsessive with power is extremely destructive and it leads to failure in healing Stella. "This is the nature of people; they unerringly select as a victim the one who needs their warmth" (McGrath 246). Stella commits suicide and she frees herself from the domination of Peter. But her suicide is barely a victory. Peter still controls her image which was done by Edgar in London and her story. Peter gives the readers a bad image of Stella when she resists him but after her death he describes her as pure, beautiful, lovely and purified from all her sins. He makes her a person who deserves sympathy of the society.

Peter's obsession with power makes him fail to grant the right treatment to the patient, Stella and leads to the tragedy. Although he represents the normalcy, social standards, mental stability and professional authority, once he is obsessed with power, he becomes unwise, dangerous and corrupt. Asylum shows how destructive power obsession is and that its effects are irreversible.

\section{Conclusion}

Obsession is a phenomenon that has a severe negative impact both on an individual obsessed as well as on those around him or her. All forms of obsessions destroy everything that it touches. Sexual obsession destroys a marital relationship as in the case of Stella who leaves her husband and son to seek happiness with Edgar. This destroys her family as due when she not with Edgar she is depressed to an extent that she just watches as her son drowns. The sexual obsession also costs her husband promotion to become the hospital superintendent as it becomes evident that his wife helped Edgar escape. The consequences of obsession make her to be judged harshly by society, and her moral integrity is questioned. People sympathize with Stella after her son dies but criticizes her when they learn that she is at the scene when her son drowns but does not try to save him.

Edgar is obsessed with jealousy to an extent that he murders his wife savagely. He also exhibits obsessional jealousy when he suspects that Stella is having a sexual relationship with his friend Nick.

Obsession with power is also evident in the story as Peter strives to win Stella and marry her. He struggles to get Stella and although he acknowledges that Stella might reject him he continues with his endeavor. He tells Stella's husband Max that he intends to marry her and advises Max to divorce her. This shows his determination of controlling those around him especially Stella. Obsession is dangerous as no one succeeds in reaching his/her aim but instead damages one's life. 
No matter how hard the obsessed person struggles to achieve his/her objectives, s/he is always doomed to fail. Stella loses her family, value and respect of society, and above all, her life. Edgar loses his wife, Stella and his freedom. Peter loses his power when Stella puts an end for life.

\section{Works Cited}

Buss, David M., and Mike Abrams. "Jealousy, infidelity, and the difficulty of diagnosing pathology: A CBT approach to coping with sexual betrayal and the green-eyed monster." Journal of Rational-Emotive \& CognitiveBehavior Therapy, vol.35, no.2, 2017, pp. 150-172.

Charny, W. A personalitydisorder of excessivepowerstrivings.NCBI, vol.34, no,1, 1997, pp.3-15.

Coles, Meredith E., and Ariel Ravid. "Clinical presentation of not-just right experiences (NJREs) in individuals with OCD: Characteristics and response to treatment." Behavior Research and Therapy, vol. 87, 2016, pp.182-187.

Gordon, William M. "Sexual obsessions and OCD." Sexual and Relationship Therapy, vol.17, no. 4, 2002, pp. 343354.

De Silva, Padmal. "Obsessive-compulsive disorder." Adult Psychological Problems.Taylor \& Francis Groups, 2014, pp.143-162.

McGrath, Patrick.Asylum. UK: Penguin Books, 1996.

McKay, Dean, et al. "Efficacy of cognitive-behavioral therapy for the obsessive-compulsive disorder."Psychiatry research, vol.225, no. 3, 2015, pp. 236-246.

Menzies, Roseeg and Silva, Padmal.Obsessive-Compulsive Disorder: Theory, Research and Treatment. UK:University of London, 2001.

Mills, C. Wright. The Power Elite. Oxford: Oxford University Press, 2000.

Oakley, Ann. Sex, gender, and society. UK: Ashgate Publishing Center, 2016.

Reisman, Mara. "Destabilizing Institutional and Social Power in Patrick McGrath's Asylum."Critique: Studies in Contemporary Fiction.Routledge, vol. 58, no. 2, 2017, pp. 156-173.

Sheikhmoonesi, Fatemeh. "Obsessional Jealousy: A Narrative Literature Review."Iranian Journal of Psychiatry and Behavioral Sciences, vol. 11, no.4, 2017, pp. 23.

Treas, Judith, Jonathan Lui, and ZoyaGubernskaya. "Attitudes on marriage and new relationships: Cross-national evidence on the deinstitutionalization of marriage." Demographic Research, vol. 30, 2014, pp. 43-55.

Tseng, Wen-Shing, and Jing Hsu. Culture and family: Problems and therapy. New York: Psychological Revivals, 1993.

Van,Bennekom, Martine J., Pelle P. de Koning, and Damiaan Denys."Social media and smartphone technology in the symptomatology of OCD.” BMJ Journals, vol.12,2018, pp.1.

Veale, David, and Alison Roberts.“Obsessive-compulsive disorder.” Clinical Research, vol. 348, 2014, pp. 13.

Wells, Adrian, et al. "Metacognitive Model and Treatment of OCD." The Wiley Handbook of Obsessive Compulsive Disorders, vol. 1, 2017, pp. 644-662. 